\title{
Analisis pengaruh inflasi, kurs dan produksi terhadap ekspor tembakau di Indonesia
}

\author{
Resa Zelvia Nolla*; Rahma Nurjanah; Candra Mustika
}

Prodi Ekonomi Pembangunan, Fak. Ekonomi dan Bisnis, Universitas Jambi

*E-mail korespondensi: resazelvia.12@gmail.com

\begin{abstract}
This study was conducted to see the contribution of tobacco exports to the total exports of the Indonesian plantation sub-sector for the period $2000-2018$ and to see the effect of inflation, exchange rates, and growth of Indonesian tobacco production on Indonesian tobacco exports for the period 2000 - 2018. The type of research used to analyze the data in this study is descriptive quantitative. This study uses multiple linear regression analysis based on Ordinary Least Square (OLS). Based on the results of the regression calculation of the development of each variable, namely inflation, exchange rates and production growth, it is obtained by these three variables that growth fluctuates throughout the research period which can be caused by economic conditions or can be caused by the influence between variables.
\end{abstract}

Keywords: Export volume, Inflation, Exchange rates, Production growth

\begin{abstract}
Abstrak
Penelitian ini dilakukan untuk melihat kontribusi ekspor tembakau terhadap total ekspor subsektor pekebunan Indonesia periode 2000 - 2018 dan untuk melihat pengaruh inflasi, kurs dan pertumbuhan produksi tembakau Indonesia terhadap ekspor tembakau Indonesia periode 2000 - 2018. Jenis penelitian yang di gunakan untuk menganalisis data dalam penelitian ini adalah deskriptif kuantitatif. Penelitian ini menggunakan analisis regresi linier berganda yang berbasis Ordinary Least Square (OLS). Berdasarkan hasil regresi perhitungan perkembangan masing-masing variabel yakni inflasi, kurs dan pertumbuhan produksi maka diperoleh oleh tiga variabel tersebut pertumbuhannya mengalami fluktuasi sepanjang dalam periode penelitian yang dapat disebabkan oleh kondisi perekonomian ataupun dapat disebabkan oleh pengaruh antar variabel.
\end{abstract}

Kata kunci: Volume ekspor, Inflasi, Kurs, Pertumbuhan produksi

\section{PENDAHULUAN}

Indonesia merupakan negara pengekspor komoditas berupa migas dan non migas. Produk ekspor Indonesia meliputi hasil produk pertanian, hasil hutan, hasil perikanan, hasil pertambangan, hasil industri dan begitupun juga jasa. Tembakau merupakan bagian dari subsektor perkebunan yang merupakan tanaman yang memiliki nilai ekonomi yang tinggi.

Perekonomian Indonesia, sektor pertanian terutama komoditi hasil perkebunan memiliki posisi penopang yang cukup besar bagi penerimaan negara dan ketenagakerjaan. Peran subsektor perkebunan dalam menunjang devisa negara cukup penting, sebab beberapa komoditi perkebunan memiliki perolehan devisa yang tinggi 
selain komoditi migas. Hasil produksi perkebunan Indonesia memegang peran penting dalam perdagangan dunia, karena hasil perkebunan Indonesia seperti karet, tembakau, teh, dan kakao termasuk pemasok kebutuhan dunia (Nazarudin, 1993).

Kegiatan ekspor berpengaruh besar terhadap daya saing setiap negara dalam era globalisasi dan perdagangan bebas antar negara saat ini. Perdagangan antar negara dikenal dengan perdagangan internasional sebenarnya sudah ada sejak zaman dahulu, namun dalam ruang lingkup dan jumlah yang terbatas dimana pemenuhan kebutuhan dalam negeri yang tidak dapat diproduksi dipenuhi dengan produksi sendiri.

Ekspor tembakau Indonesia berfluktuasi, salah satu disebabkan karena pada 1993 - 1996 sempat menurun, namun naik lagi pada 1997 dan kembali turun lagi pada 1999 2000. Jumlah ekspor tembakau tahun 2010 yaitu sebesar 57.408 ton, dan turun pada tahun berikutnya yaitu sebesar 38.905 ton pada tahun 2011. Pada tahun 2012 jumlah ekspor tembakau di Indonesia adalah sebesar 37.110 ton, kemudian tahun 2013 terjadi kenaikan sebesar 41.765 ton. Pada tahun 2014 ekspor tembakau kembali turun menjadi 35.009 ton dan turun lagi pada tahun 2015 julmah ekspor sebesar 30.675 ton, kemudian tahun dua tahun berikutnya terjadi penurunan yaitu sebesaar 28.005 ton pada tahun 2016 dan tahun 2017 sebesar 28.796 ton. Hingga tahun 2018 jumlah ekspor tembakau Indonesia adalah sebesar 23.069 ton.

Nilai ekspor tembakau di Indonesia berdasarkan Pusat Data dan Informasi pertanian Indonesia 2018 nilai ekpor tembakau juga mengalami fluktuasi dari tahun ke tahun periode 2000 - 2018. Dilihat dari 5 tahun terakhir nilai ekspor tembakau cendrung tida stabil, pada tahun 2014 nilai ekspor tembakau di Indonesia adalah 83.165.700 US\$ dan kemudian turun pada tahun berikutnya yaitu pada tahun 2015 hingga menjadi 59.106.100 US\$. Nilai ekspor tembakau tahun 2016 adalah sebesar 50.000.000 US\$, dan tahun 2017 meningkat dari tahun sebelumnya sebesar 55.900.000 US\$, kemudian tahun 2018 ekspor tembakau Indonesia sebesar 67.800.000 US\$.

Inflasi merupakan merupakan suatu proses meningkatnya harga secara umum dan terus-menerus berkaitan dengan mekanisme pasar yang dapat disebabkan oleh faktorfaktor tertentu. Di Indonesia inflasi berfluktuasi atau tidak stabil, dilihat dari tahun 2014 tingkat inflasi di Indonesia sebesar $8,36 \%$ dan mengalami penurunan yang sangat drastis pada tahun 2015 ke angka 3,35 \%, sedangkan pada tahun berikutnya tidak terlalu berfluktuasi yaitu berkisar antara $3,02 \%$ pada tahun 2016, dan naik tahun berikutnya menjadi 3,61\% yaitu pada tahun 2017. Pada tahun 2018 tingkat inflasi yaitu sebesar $3,13 \%$. Hal ini menunjukkan bahwa ekonomi Indonesia sudah cukup stabil, jika dilihat dari tingkat inflasi 5 tahun terakhir.

Kurs dapat mendorong peningkatan dan penurunan ekspor. Dalam perkembangan perdagangan internasional, valuta asing terhadap rupiah memiliki peran yang sangat penting untuk melakukan pembayaran transaksi. Karena dalam melakukan perdagangan internasional suatu negara dengan negara lainnya pasti akan memerlukan satuan mata uang yang sama dan dapat diterima secara universal. Menurut Agung, (2010) "ketika nilai tukar rupiah terdepresiasi terhadap dollar, maka menyebabkan harga barang-barang impor meningkat, dan sebaliknya harga barang-barang ekspor menjadi turun".

Ekspor adalah aktivitas menjual produk suatu negara ke negara lain. Menurut tambunan (2001) ekspor adalah mengirim komoditi dalam negeri keluar negeri akibat terjadinya suatu transaksi perdagangan antara kedua belah pihak negara. Ekspor sangat besar peranannya bagi perekonomian suatu negara khususnya negara yang sedang berkembang termasuk negara Indonesia. Dapat dilihat dari manfaatnya yang diberikannya baik secara langsung maupun tidak langsung. 
Menurut Perdana (2010), ekspor pada awalnya komoditi yang dihasilkan oleh produsen hanya ditawarkan di dalam negeri, tetapi seiring meningkatnya kebutuhan dunia akan barang dan jasa dan adanya negara yang tidak dapat memenuhi kebutuhannya sendiri maka negara yang dapat menghasilkan suatu komoditi dalam jumlah besar akan melakukan ekspor kepada negara yang membutuhkan komoditinya. Oleh karena itu dapat disimpulkan bahwa ekspor adalah upaya untuk melakukan penjualan komoditi yang dimiliki kepada bangsa lain dengan mengharapkan pembayaran dalam bentuk valuta asing.

Penawaran suatu komoditas baik berupa barang maupun jasa adalah jumlah yang ditawarkan oleh produsen pada konsumen dalam suatu pasar dalam tingkat harga dan waktu tertentu. Biasanya jumlah penawaran di iringi dengan jumlah permintaan agar tidak mempengaruhi harga, seperti suatu perusahaan akan mengurangi produksi, jika permintaan berkurang dan sebaliknya, jika permintaan meningkat suatu perusahaan lebih dominan untuk meningkatkan produksi. Jumlah produksi sangat mempengaruhi ekspor dan akan memperoleh manfaat perdagangan internasional dengan spesialisasi produksi dan mengekspor barang jika negara tersebut memiliki keunggulan mutlak, dan akan mengimpor barang jika negara tersebut memiliki ketidak unggulan mutlak (Hamdy, 2001). Maka peneliti menggambil judul tentang analisis pengaruh inflasi, kurs dan produksi terhadap ekspor tembakau di Indonesia.

\section{METODE}

\section{Jenis dan sumber data}

Penelitian ini menggunakan jenis data sekunder. Data sekunder adalah data yang berkala atau runtut waktu (times series) yang dikumpulkan untuk menggambarkan tentang kontribusi ekspor di Indonesia dari tahun 2000-2018 yang diperoleh dari berbagai sumber yaitu: Direktorat jendral perkebunan, Badan pusat Statistik, dan Bank Indonesia. Kajian ini dilakukan dengan pendekatan metode penelitian kuantitatif.

\section{Analisis deskriptif}

Analisis deskriptif adalah analisis yang dilakukan untuk menilai karateristik dari sebuah data dengan cara memberikan gambaran. Tujuan dari analisis deskriptif ini adalah untuk menyajikan gambaran secara sistematis dan akurat mengenai hubungan antar fenomena yang diteliti. Analisis deskriptif dalam penelitian ini digunakan untuk menjawab tujuan pertama yaitu mengetahui berapa besar kontribusi ekpsor tembakau di Indoneisa terhadap keseluruhan total ekspor perkebunan di Indonesia tahun 2000- 2018. Untuk menjawab tujuan yang pertama digunakan rumus sebagai berikut:

$$
\begin{aligned}
& K T(\%)=\frac{N E}{N S P} \times 100 \% \\
& \text { KT } \quad \text { : Kontribusi ekspor tembakau di Indonesia (\%) } \\
& \text { NE } \quad \text { : Jumlah ekspor tembakau di Indonesia } \\
& \text { NSP } \quad \text { Jumlah keseluruhan ekspor sub sektor perkebunan }
\end{aligned}
$$

\section{Analisis kuantitatif}

Untuk menganalisis pengaruh inflasi, kurs, dan produksi tembakau terhadap volume ekspor tembakau Indonesia dengan menggunakan analisis regresi linear berganda. Untuk menjawab tujuan kedua digunakan rumus regresi linear berganda sebagai berikut: $\mathrm{Y}=\mathrm{f}\left(\mathrm{X}_{1}, \mathrm{X}_{2}, \mathrm{X}_{3}\right)$ 
Fungsi yang telah dijabarkan sebelumnya dimasukkan dalam bentuk model regresi linier berganda pada ekonometrika, berikut model estimasi ekspor tembakau Indonesia yang digunakan dalam penelitian ini:

$$
\begin{aligned}
& Y=\beta_{0}+\beta_{1} X_{1 t}+\beta_{2} X_{2 t}+\beta_{3} X_{3 t}+\varepsilon \\
& E K S=\beta_{0}+\beta_{1} I N F L_{t}+\beta_{2} K U R S_{t}+\beta_{3} \text { PROD }_{t}+\varepsilon
\end{aligned}
$$

Dimana :

EKS : Ekspor tembakau

$\beta_{0} \quad$ : Konstanta

$\beta_{1}, \beta_{2}, \beta_{3}$ : Koefisien regresi

INFL : Tingkat inflasi

KURS : Nilai tukar rupiah

PROD : Produksi

\section{Pengujian hipotesis}

\section{Uji F statistik (uji bersama-sama)}

Uji F digunakan untuk melihat tingkat signifikan pengaruh variabel indenpenden secara bersama-sama (simultan) terhadap variabel dependen. Nilai F hitung didapat dengan menggunakan rumus:

Dimana :

$$
F=\frac{R^{2} /(K-1)}{\left(1-R^{2)} /(K-1)\right.}
$$

$F: F_{\text {hitung }}$

$R^{2}:$ Koefisien determinasi

$\mathrm{K}$ : jumlah variabel

$\mathrm{N}$ : jumlah sampel

Penilaian dilakukan dengan membandingkan nilai $\mathrm{F}$ hitung dengan $\mathrm{F}$ tabel pada derajat kebebasan (df) dan tingkat keyakinan tertentu dengan ketentuan sebagai berikut: H0: variabel indenpenden inflasi, kurs, dan produksi secara bersama-sama tidak berpengaruh terhadap volume ekspor tembakau Indonesia. Atau H1: variabel indenpenden inflasi, kurs, dan produksi secara bersama-sama berpengaruh terhadap volume ekspor tembakau Indonesia.

\section{Uji t-statistik (uji parsial)}

Uji ini digunakan untuk mengetahui secara parsial seberapa besar pengaruh tingkat signifikan variabel bebas (indenpenden) yaitu inflasi, kurs, luas areal dan produksi secara individu (parsial) berpengaruh terhadap variabel terikat, yaitu volume ekspor tembakau Indonesia, dengan asumsi variable lain di anggap konstan. terhadap variabel terikat (dependen). Nilai t hitung diperoleh dari rumus :

Dimana :

$$
t=\frac{b_{i}}{S e\left(b_{i}\right)}
$$

$\mathrm{t}: t_{\text {hitung }}$ 
$b_{i} \quad:$ koefisien regresi

$S e b_{i}:$ standar error

Dengan membandingkan $t_{\text {hitung }}$ dan $t_{\text {tabel }}$ pada tingkat keyakinan tertentu dapat diambil kesimpulandengan kreteria sebagai berikut: Apabila $t_{\text {hitung }}>t_{\text {tabel }}$, maka H0 ditolak, dan Apabila $t_{\text {hitung }}<t_{\text {tabel, }}$ maka H0 diterima .

Uji t juga dapat dengan melihat nilai t statistik pada tingkat signifikan $10 \%$. Apabila tingkat signifikan lebih kecil dari $\alpha=10 \%$, maka $\mathrm{H} 0$ ditolak dan $\mathrm{H} 1$ diterima yang artinya bahwa secara parsial variabel bebas berpengaruh secara signifikan terhadap variabel terikay, sebaliknya tingkat signifikan lebih besar dari $\alpha=10 \%$, maka H0 diterima dan H1 ditolak yang artinya bahwa secara parsial variabel bebas tidak berpengaruh secara signifikan terhadap variabel terikat.

\section{Uji koefisien determinasi $\left(\mathbf{R}^{2}\right)$}

Uji ini digunakan untuk mengetahui seberapa besar proporsi sumbangan seluruh variabel indenpenden terhadap variabel variasi naik turunnya variabel tidak bebas. Nilai $\mathrm{R}^{2}$ berikisar antara 0 samapai dengan 0 - 1, jika mendekati 0 berarti kurang kuat hubungan antara variabel dependendengan variabel independen. Jika nilainya mendekati 1 maka menunjukkan semakin besarnya antar kedua hubungan variabel tersebut. Sementara nilai $\mathrm{R}$ menunjukkan hubungan antar variabel indenpenden (X). Nilai R terletak antara -1 sampai 0, dan hubungan kedua variabel tersebut.

\section{Uji multikolinieritas}

Uji multikolinearitas dapat dideteksi dengan menghitung koefisien ganda dan membandingkannya dengan koefisien korelasi antar variabel bebas. Uji multikolinearitas dengan eviews dilakukan dengan melihat uji regresi, dengan nilai patokan VIF (variance inflation faktor) dan koefisien korelasi antar variabel bebas (Sulistyo, 2010) kreteria yang digunakan adalah: Jika nilai VIF disekitar angka 1 atau memiliki toleransi mendekati 1, maka katakan tidak terdapat masalah multikolinearitas dan Jika koefisien korelasi antar variabel bebas kurang dari 0,5 maka tidak terdapat masalah multikolinearitas.

\section{Uji heteroskedastisitas}

Asumsi dalam model regresi adaalah dengan memenuhi (1) residual memiliki nilai rata-rata nol, (2) residual memiliki varian yang konstan, dan (3) residual suatu observasi tidak saling berhubungan dengan residual observasi lainnya sehingga menghasilkan estimator yang BLUE. Apabila asumsi (1) terpenuhi yang terpengaruh hanyalah slope estimator dan ini tidak membawa koefisien serius dalam analisis ekonometrik. Sedangkan jika asumsi (2) dan (3) tidak terpenuhi, maka akan berdampak pada prediksi dengan model yang dibangun.

Dalam kenyataannya, nilai residual sulit memiliki varian yang konstan. Hal ini sering terjadi pada data yang bersifat cross section dibanding time series (Wahyu, 2011). Metode yang dapat digunakan untuk mengidentifikasi ada tidaknya masalah heteroskedastisitas adalah uji white.

\section{Uji autokorelasi}

Autokorelasi bertujuan untuk mengetahui apakah dalam sebuah model regresi linear ada korelasi antara kesalahan penggangu pada periode $t$ dengan kesalahan pada periode t-I (sebelumnya). Tentu saja model regresi yang baik adalah regresi bebas dari autokorelasi (Gujarati 2007). Autokorelasi menurut Wahyu, (2011) dapat 
berbentuk autokorelasi positif dan autokorelasi negatif. Mengidentifikasi adanya autokorelasi dapat dilakukan dengan melakukan dua cara, yakni Uji Durbin-Watson dan Uji Cochrane-Orcutt.

Apabila D-W berada diantara 1,69 hingga 2.31 maka model tersebut tidak terdapat autokorelasi. Sebaliknya, jika DW tidak berada diantara 1,69 hingga 2,31 maka model tersebut terdapat autokorelasi (Wahyu, 2011).

\section{Uji normalitas}

Uji Normalitas bertujuan untuk menguji apakah nilai residual terdistribusi normal atau tidak pada variabel terikat dan variabel bebas. Model regresi yang baik adalah memiliki nilai residual yang terdistribusi normal. Uji normalitas diantaranya dilakukan dengan dua cara, yaitu histogram dan uji Jarque-Bera (J-B). Untuk melihat data terdistribusi normal atau tidak adalah dengan melihat koefisien J-B dan probabilitasnya. Bila nilai J-B tidak signifikan (lebih kecil dari 5\%) maka data terdistribusi tidak normal. Sedangkan bila probabilitas lebih besar dari 5\%, maka data terdistribusi normal (Wahyu, 2011).

\section{HASIL DAN PEMBAHASAN}

\section{Kontribusi sektoral terhadap PDB Indonesia tahun 2017-2018}

Perekonomian Indonesia masih mengalami guncangan dari adanya ketidakpastian pada tingkat global. Pelemahan kurs rupiah tetap membayang-bayangi kondisi perekonomian dan dikhawatirkan membawa Indonesia ke krisis seperti kondisi 1997. Namun, kondisi ekonomi Indonesia hampir berada di lampu merah, Untuk menjawab kekahawatiran itu, maka penting suatu negara untuk memahami indikator-indikator kunci makroekonomi. Rata-rata Kontribusi sektor ekonomi terhadap PDB di Indonesia tahun 2017 yaitu sebesar 5,22\% dan naik pada tahun 2018 yaitu sebesar 5,61\%.

Kontribusi sektor ekonomi terhadap PDB di Indonesia tahun 2017 yang paling besar yaitu pada sektor informasi dan komunikasi, dengan kontribusi sebesar 9,81\% dan kontribusi sektor ekonomi terhadap PDB di Indonesia yang paling kecil pada periode 2017 yaitu pada sektor petambangan dan penggalian dengan kontribusi sebesar 0,69\%. Sedangkan tahun 2018 yang paling besar yaitu pada sektor industri, dengan kontribusi sebesar 19,82\% dan kontribusi sektor ekonomi terhadap PDB di Indonesia yang paling kecil pada periode 2018 yaitu pada sektor pengadaan air dengan kontribusi sebesar $0,07 \%$. Untuk lebih jelas lihat pada Gambar 1berikut. 


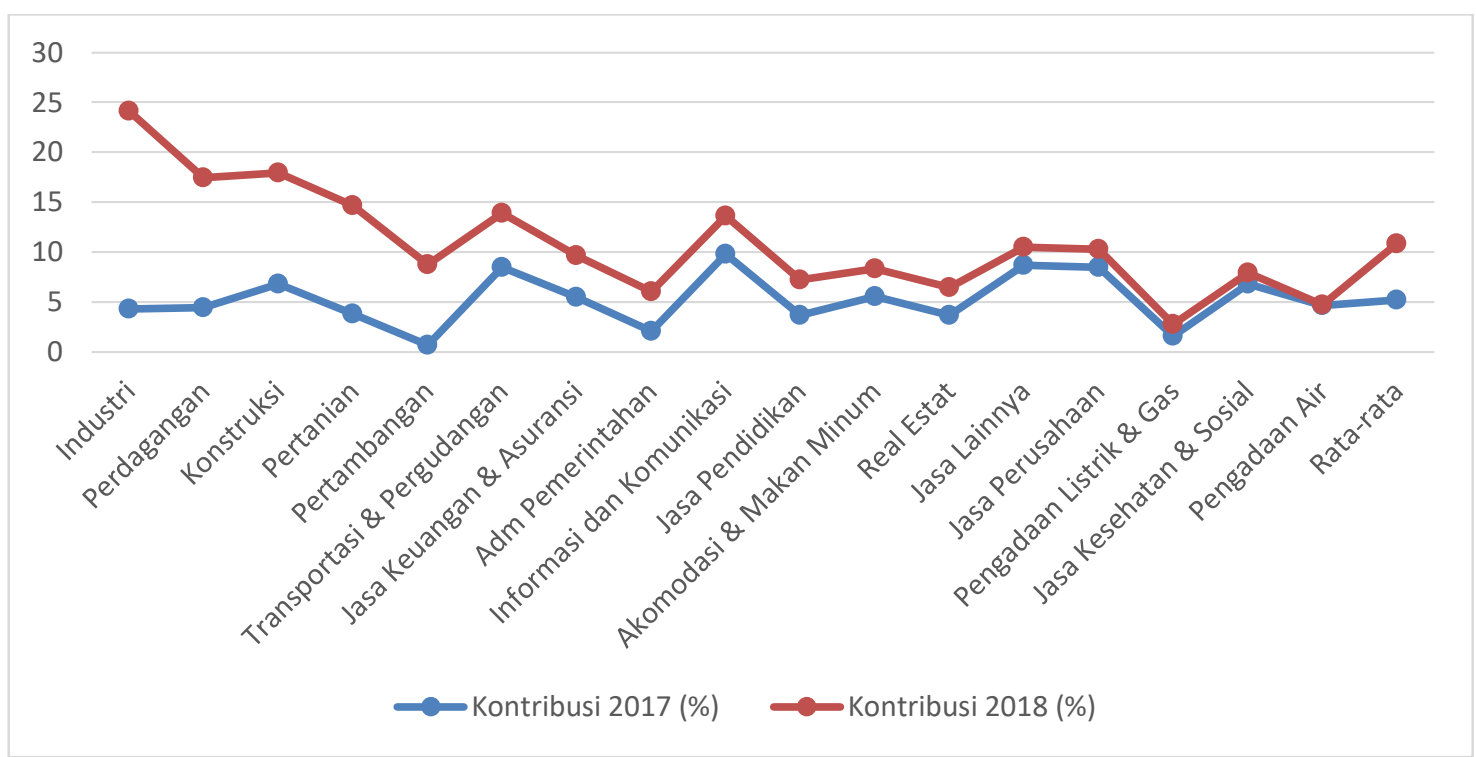

Sumber: Data diolah, 2019

Gambar 1. Kontribusi ekspor tembakau terhadap ekspor perkebunan Indonesia

Kontribusi sektor ekonomi terhadap PDB di Indonesia periode 2017 dan 2018 pada sektor industri sebesar 4,27\% dan meningkat $19,82 \%$, kemudian pada sektor perdagangan tahun 2017 kontribusi terhadap PDB sebesar 4,44\% dan meningkat $13,00 \%$ pada tahun 2018. Selanjutnya kontribusi sektor kontruksi terhadap PDB di Indonesia periode 2017 yaitu sebesar 6,79\% dan meningkat sebesar $11,11 \%$ pada tahun 2018, pada tahun 2017 sektor pertanian memiliki kontribusi terhadap PDB sebesar $3,81 \%$ dan meningkat pada tahun berikutnya yaitu sebesar 10,88\% pada tahun 2018 . Pada sektor pertambangan memiliki kontribusi terhadap PDB di Indonesia periode 2017 yaitu sebesar $0,69 \%$ dan meningkat sebesar 8,03\% pada tahun 2018. Berbeda dengan sektor transportasi dan pergudangan jika sektor sebelumnya meningkat dari tahun 2017 ke tahun 2018, namun sektor ini menurun yaitu kontribusinya tahun 2017 sebesar $8,49 \%$ dan menurun ke angka 5,39\% tahun 2018. Selanjutnya sektor jasa keuangan dan asuransi berkontribusi terhadap PDB pada tahun 2017 sebesar 5,48\% dan menurun pada tahun 2018 menjadi 4,17\%.

Pada sektor administrasi pemerintahan memiliki kontribusi terhadap PDB di Indonesia periode 2017 yaitu sebesar 2,06\% dan meningkat pada tahun berikutnya menjadi 3,94\% pada tahun 2018. Kemudian pada sektor informasi dan komunikasi memiliki kontribusi terhadap PDB tahun 2017 sebesar 9,81\% dan menurun pada tahun 2018 menjadi 3,83\%. Selanjutnya kontribusi jasa pendidikan terhadap PDB tahun 2017 yaitu sebesar 3,66\% dan tahun 2018 menunjukkan angka sebesar 3,54\%. Sektor akomodasi dan makan minum memberi kontribusi terhadap PDB pada tahun 2017 yaitu sebesar 5,55\% dan kemudian menurun pada tahun 2018 menjadi 2,79\%. Pada sektor real estat memberi kontribusi terhadap PDB yaitu sebesar 3,68\% pada tahun 2017 dan kemudian turun sebesar 2,74\% pada tahun 2018.

Kontibusi sektoral terhadap PDB cendrung berubah-ubah, seperti pada sektor jasa lainnya memberikan kontribusi terhadap PDB tahun 2017 sebesar 8,66\% dan kemudian turun pada tahun 2018 kontribusi sebesar 1,84\%. Pada sektor pangadaan listrik dan gas memberi kontribusi terhadap PDB sebesar 1,54\% pada tahun 2017 dan menurun pada tahun berikutnya menjadi $1,21 \%$ pada tahun 2018 . Namun pada sektor jasa kesehatan dan sosial memberi kontribusi terhadap PDB Indonesia jugan mengalami penurunan dari tahun 2017 ke 2018, dimana kontribusi nya dari 6,79\% menjjadi 1,11\%. Terakhir yaitu sektor pengadaan air juga ikut mengalami penurunan dari tahun 2017 ke tahun 
2018, kontribusi sektor pengadaan air terhadap PDB Indonesia yaitu sebesar 4,61\% tahun 2017 dan turun ke angka 0,07\% pada tahun 2018.

Indonesia merupakan negara agrasis, dimana sektor pertanian merupakan sektor yang paling banyak digeluti oleh penduduknya. Namun dari tabel terlihat sektor industri yang memiliki kontrbusi terbesar terhadap PDB indonesia pada tahun 2018, dan sektor pertanian bereda pada no urut empat. Hal ini menandakan terjadinya penurunan pada sektor pertanian, dari hal itu perlu adanya kajian ilmiah terhadap sektor pertanian di Indonesia.

\section{Kontribusi ekspor tembakau dalam periode 2000-2018}

Ada beberapa faktor yang dibahas dalam penelitian ini, diantaranya adalah inflasi, kurs dan produksi tambakau Indonesia. Rata-rata kontribusi nilai ekspor tembakau terhadap keseluruhan total nilai ekspor subsektor perkebunan di Indonesia dalam periode tahun 2000 - 2018 yaitu sebesar 2,59\% setiap tahunnya. Kontribusi ekspor tembakau terhadap keseluruhan total nilai ekspor subsektor perkebunan di Indonesia yang tertinggi terjadi pada tahun 2001 yaitu memberikan kontribusi sebesar 23,21\%. dan kontribusi ekspor tembakau yang paling rendah selama periode 2000-2018 yaitu terjadi pada tahun 2017 dimana kontribusi ekspor tembakau hanya sebesar $0,18 \%$. Untuk data 5 tahun terakhir lihat grafik perkembangan kontribusi ekspor tembakau terhadap keseluruhan total ekspor perkebunan di Indonesia. Kontribusi ekspor tembakau terhadap total ekspor subsektor perkebunan di Indonesia mengalami siklus yang berfluktuasi kontribusi ekspor tembakau terhadap keseluruhan total ekspor sub sektor perkebunan, hingga tahun 2014 yaitu sebesar $0,28 \%$.

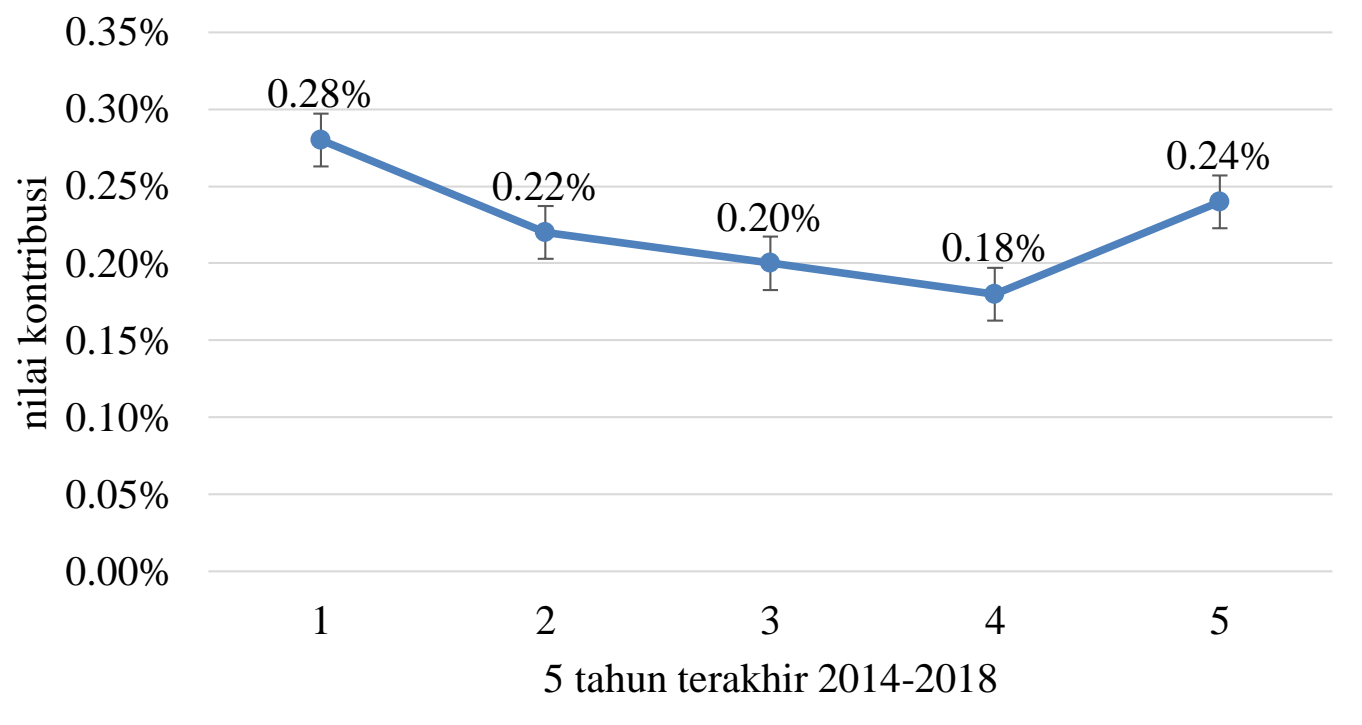

Sumber: Data diolah, 2019

Gambar 2. Kontribusi ekspor tembakau terhadap ekspor perkebunan Indonesia

Berdasarkan gambar 2 menunjukkan bahwa ekspor tembakau Indinesia tidak begitu stabil, dilihat pada tahun 2015 kontribusi nilai ekspor tembakau terhadap keseluruhan total nilai ekspor subsektor perkebunan di Indonesia adalah sebesar 0,22\% dan pada tahun 2016 kontribusi ekspor tembakau Indonesia yaitu sebesar 0,20\%. Kemudian pada tahun 2017 kontribusi ekspor tembakau terhadap subsektor perkebunan di Indonesia menunjukkan angka sebesar 0,18\%, dan dilanjutkan pada tahun 2018 kontribusi ekspor tembakau sebesar 0,24\%.

\section{Hasil regresi linear berganda}


Untuk menghitung dan menganalisis hubungan dan pengaruh antara variabel inflasi, kurs, dan produksi tembakau, dgunakan analisis regresi berganda, dengan menggunakan data yang ada dan dengan menggunakan perangkat lunak komputer yaitu program Eviews 10 maka dapat kita lihat apakah variabel yang telah ditentukan memiliki pengaruh yang signifikan terhadap aktivitas ekspor tembakau di Indonesia (volume ekspor), maka perhitungan regresi dengan persamaan:

$$
Y=\beta_{0}+\beta_{1} X_{1 t}+\beta_{2} X_{2 t}+\beta_{3} X_{3 t}+\varepsilon
$$

Berdasarkan model di atas dan hasil perhitungan yang telah dilakukan dengan menggunakan aplikasi komputer Eviews 10, maka diperoleh nilai regresi berganda sebagai berikut:

Tabel 1. Hasil Regresi linear berganda

\begin{tabular}{ccccc}
\hline Variable & Coefficient & Std. Error & t-Statistik & Prob. \\
\hline C & 76.13657 & 8.553983 & 8.900715 & 0.0000 \\
INFL & 0.561145 & 0.355672 & 1.577703 & 0.1355 \\
KURS & -3.558609 & 0.687061 & -5.179470 & 0.0001 \\
PROD & -0.123782 & 0.051210 & -2417163 & 0.0288 \\
\hline R-squared & 0.734226 & Mean dependent var & 41.39958 \\
F-statistik & 13.81299 & Durbin-watson stat & 0.924175 \\
\hline
\end{tabular}

Sumber : Data di olah, 2019

Berdasarkan Tabel 1, maka dapat ditulis persamaan regresi sebagai berikut:

\section{$Y=76.13657+0.561145$ inflasi -3.558609 kurs -0.123782 produksi $+\varepsilon$}

Persamaan regresi linear berganda tersebut dapat di interprestasikan sebagai berikut:Hasil perhitungan statistik dapat diketahui nilai koefisien nilai konstan dari persamaan tersebut adalah sebesar 76.13657. Dimana artinya jika nilai inflasi, kurs dan produksi pada periode tahun 2000 - 2018 tidak berubah maka ekspor tembakau akan meningkat sebesar 76.13657 ton.

Pada hasil regresi untuk variabel inflasi diperoleh koefisien sebesar 0.561145 . Berarti apabila inflasi meningkat sebesar 1 persen maka volume ekspor tembakau akan meningkat sebesar 0.561145 ton dan begitu pula sebaliknya. Semakin tinggi peningkatan inflasi maka nilai ekspor tembakau akan semakin meningkat.

Pada hasil regresi untuk variabel kurs diperoleh koefisien sebesar 3.558609 . Berarti apabila kurs terapresiasi sebesar 1 rupiah maka volume ekspor tembakau akan meningkat sebesar 3.558609 ton dan begitu pula sebaliknya jika kurs terdepresiasi 1rupiah maka volume ekspor akan turun sebesar 3.558609. Semakin terdepresiasi kurs maka volume ekspor tembakau akan semakin turun.

Pada hasil regresi untuk variabel produksi diperoleh koefisien sebesar 0.123782. Berarti apabila terjadi pertumbuhan produksi meningkat sebesar 1 persen maka nilai ekspor tembakau akan turun sebesar 0,123782 ton dan begitu pula sebaliknya. Semakin tinggi peningkatan produksi maka volume ekspor tembakau akan semakin turun.

\section{Pengujian hipotesis}

\section{Hasil uji F (uji bersama-sama)}

Uji $\mathrm{F}$ digunakan untuk melihat apakah variable indenpendent berpengaruh terhadap variabel dependent dengan level pf signifikance 5\%. Dari hasil yang diperoleh 
adalah untuk nilai F-hitung adalah sebesar 13.81299 dengan probabilitas sebesar 0,000137 atau lebih kecil dari $\alpha=5 \%(0,000137<0,05)$. Dengan demikian maka H0 ditolak dan $\mathrm{H} 1$ diterima pada tingkat keyakinan 95\%, yang mengidentifikasikan bahwa Inflasi (X1), Kurs (X2) dan Produksi (X3) secara bersama-sama berpengaruh terhadap Volume Ekspor (Y).

\section{Hasil uji t-Statistik (uji parsial)}

Berdasarkan hasil olahan data diperoleh nilai prob. kurs dan produksi tembakau Indonesia lebih kecil dari tingkat signifikansi 5\% dan t statistik untuk kurs dan produksi bernilai negatif. Hal ini menunjukkan bahwa kurs dan produksi tembakau Indonesia berpengaruh negatif dan signifikan terhadap ekspor tembakau Indonesia. Sedangkan inflasi tidak berpengaruh terhadap ekspor tembakau di Indonesia.

\section{Hasil uji koefisien determinasi $\left(\mathbf{R}^{2}\right)$}

Berdasarkan hasil olahan data diperoleh nilai koefisien determinansi (R-Squared) sebesar 0,734226 yang berkisar antara $73,4 \%$ variabel volume ekspor tembakau di Indonesia ditentukan oleh inflsi, kurs dan produksi terhadap ekspor tembakau, dan $26,6 \%$ yang mempengaruhi volume ekspor tembakau di Indonesia oleh faktor-faktor lain yang tidak diteliti dalam penelitian.

Dapat diketahui dari Tabel 2, hasil uji multikolinearitas menggunakan eviews 10 bahwa nilai center VIF dari masing-masing variabel tidak terdapat yang lebih besar dari 10, artinya semua variabel bebas tidak terindikasi gejala multikolinearitas. Dapat disimpulkan dari beberapa nilai korelasi antar variabel diatas bahwa model ini lolos dari multikolinearitas.

Tabel 2. Hasil uji terhadap gejala multikolinearitas

\begin{tabular}{cccc}
\hline Variable & $\begin{array}{c}\text { Coefficient } \\
\text { Variance }\end{array}$ & $\begin{array}{c}\text { Uncentered } \\
\text { VIF }\end{array}$ & $\begin{array}{c}\text { Centered } \\
\text { VIF }\end{array}$ \\
\hline C & 73.17063 & 45.96345 & NA \\
INFL & 0.126503 & 4.898765 & 1.113709 \\
KURS & 0.472052 & 35.01745 & 1.116027 \\
PROD & 0.002622 & 1.077444 & 1.043773 \\
\hline
\end{tabular}

Sumber : Data di olah, 2019

Tabel 3. Hasil uji terhadap gejala heterokedastisitas

\begin{tabular}{|c|c|c|c|}
\hline \multicolumn{4}{|c|}{ Heterokedastisitas test: white } \\
\hline F-statistic & 0.497069 & Prob.F $(9,9)$ & 0.8438 \\
\hline Obs*R-squared & 6.308534 & Prob. Chi-Square(9) & 0.7087 \\
\hline Scaled explained SS & 1.933789 & Prob. Chi-Square(9) & 0.9925 \\
\hline
\end{tabular}

Heterokedatisitas terjadi saat residual dan nilai prediksi memiliki pola hubungan. Pola hubungan ini tidak hanya sebatas hubungan linear, tetapi juga berbeda. Metode uji gejala heterokedatisitas yang digunakan adalah white. Apabila nilai Prob. F hitung lebih besar dari 0,05 maka tidak terindikasi adanya gejala eviews 10. Berdasarkan hasil uji white, pada tabel 3, dapat diketahui nilai Prob F hitung sebesar $0.8438>0,05$, maka dapat disimpulkan tidak terdapat gejala heterokedatisitas atau model ini bebas dari gejala heterokedatisitas. 
Tabel 4. Hasil uji Terhadap Gejala Autokolerasi

\begin{tabular}{cccc}
\hline \multicolumn{5}{l}{ Beusch-Godfrey Serial Correlation LM Test: } \\
\hline F-statistik & 2.679449 & Prob. F(2,13) & 0.1061 \\
ObsR-squared & 5.546033 & Prob. Chi-Square(2) & 0.0625 \\
\hline
\end{tabular}

Sumber: Data diolah, 2019

Untuk mengetahui indikasi gejala autokorelasi dihunakan metode BreuschGodfrey atau disebut dengan uji Lagrange Multiplier, yang mana jika probabilita lebih kecil dari 0,05 maka terindikasi geaja autokorelasi. Berikut hasil uji autokorelasi dengan menggunakan software eviews 10. Berdasarkan data diatas dapat dilihat bahwa nilai Prob. $F(2,13)$ sebesar 0,1061 yang artinya tidak ada gejala autokorelasi, maka model ini lolos dari uji terhadap gejala autokorelasi.

\section{Hasil uji terhadap gejala normalitas}

Berdasarkan uji normalitas yang telah dilakukan, diperoleh nilai Jarque-bera sebesar 0,835680 dengan probabilitas 0,658468, sehingga dapat disimpulkan, bahwa probabilitas dari Jarque-bera 0,658468 lebih besar dari alpha 5\%. Artinya bahwa residual terdistribusi secara normal, sehingga asumsi klasik tentang kenormalan pada model regresi berganda berbasis Ordinary Least Square sudah terpenuhi. Untuk lebih jelas lihat pada gambar berikut.

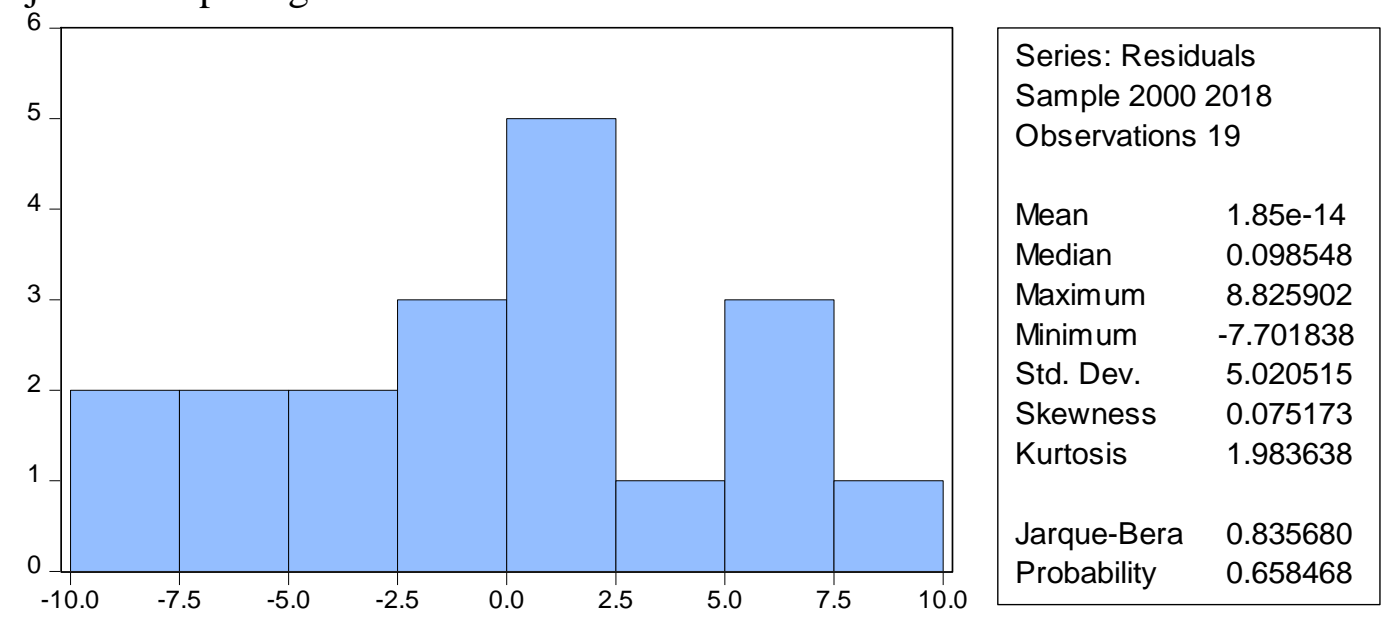

Sumber: Data diolah, 2019

Gambar 3. Hasil uji terhadap gejala normalitas

\section{Pengaruh kurs terhadap ekspor}

Koefisien regresi untuk variabel kurs diperoleh koefisien sebesar 3.558609 . Nilai ini berarti apabila kurs terdepresiasi sebesar 1 Rupiah maka volume ekspor tembakau akan turun sebesar 3.558609 ton dan begitu pula sebaliknya. Semakin terapresiasi kurs maka volume ekspor tembakau akan semakin turun. Berdarkan hasil pengujian nilai kurs rupiah terhadap dollar berpengaruh negatif dan signifikan, yang berarti terdepresiasinya kurs rupiah maka akan menurunkan nilai ekspor tembakau. Disaat kurs terdepresiasi maka ekspor tembakau akan menurun hal ini disebabkan adanya kebijakan-kebijakan tertentu yang dibuat oleh pemeritah yang berdampak pada volume ekspor tembakau di Indonesia, salah satunya yaitu adanya aturan tentang pelarangan penggunaan zat adiktif yang dimana bahan bakunya yaitu tembakau. Penelitian ini sejalan dengan, Putu dan martini (2015), yang menyatakan pengaruh kurs bahwa variabel kurs berpengaruh negatif terhadap ekspor teh Indonesia ke Jerman. 


\section{Pengaruh produksi tembakau terhadap ekspor}

Koefisien regresi untuk variabel produksi diperoleh koefisien sebesar 0.123782. Nilai ini berarti apabila terjadi pertumbuhan produksi meningkat sebesar 1 persen maka volume ekspor tembakau akan turun sebesar 0,123782 ton dan begitu pula sebaliknya. Semakin tinggi peningkatan produksi maka volume ekspor tembakau akan semakin turun. Produksi berpengaruh negatif dan signifikan terhadap volume ekspor tembakau Di Indonesia, yang artinya jika terjadi peningkatan perkembangan produksi maka akan menurunkan tingkat ekspor tembakau di Indonesia.

Berdasarkan konsep dari Soekartiwi (2005) menjelaskan bahwa salah satu faktor terjadi nya ekspor adalah adanya kelebihan produksi dalam negeri dan adanya permintaan barang dariluar negeri. Hal ini disebabkan oleh adanya pelaku eksportir yang melakukan penundaan ekspor dengan alasan eksportir takut menjual produk lebih murah karena pada tahun tertentu penawaran produk tembakau surplus, sehingga dengan adanya stok maka membantu mestabilkan harga bagi produsen tembakau dalam melindungi diri sendiri, karena juga mengingat tembakau merupakan komoditi yang tehan lama. Selain itu juga teknologi yang kurang modern, lahan yang tidak produktif dan kenaikkan tarif cukai tembakau yang memberi pengaruh negatif terhadap volume ekspor tembakau di Indonesia. Penelitian ini juga sejalan dengan penelitian Azmy, dkk (2016), menunjukkan bahwa semakin naik nya produksi tembakau domestik, semakin menurunkan nilai ekspor nya. Hal ini dikarenakan kualitas dan jenis tembakau Indonesia yang kurang dapat bersaing di pasar dunia mempengaruhi permintaan dan penawaran tembakau Indonesia.

\section{KESIMPULAN DAN SARAN}

\section{Kesimpulan}

Kontribusi ekspor komoditi tembakau pada periode 2000-2018 memiliki trend yang berfluktuasi dengan kontribusi rata-rata sebesar 2,59\%. Kontribusi ekspor tembakau terhadap keseluruhan total nilai ekspor subsektor perkebunan di Indonesia terendah terjadi pada tahun 2017 hanya memberikan kontibusi sebesar 0,18\%, dan kontribusi ekspor tembakau tertinggi terjadi pada tahun 2000 yaitu memberikan kontribusi sebesar 23,21\%. Dan berdasarkan hasil regresi variabel inflasi dan kurs berpengaruh signifikan terhadap volume ekspor tembakau di Indonesia.

\section{Saran}

Kontribusi ekspor tembakau hendaknya dapat di maksimalkan, dengan memaksimalkan lahan yang lebih produktif, bibit unggul dan teknologi yang lebih modren dalam memproduksi tembakau agar komoditi tembakau memberi dampak positif dan mampu bersaing di pasar internasional. Pemerintah diharapkan lebih memperhatikan faktorfaktor yang dapat mempengaruhi tingkat volume ekspor tembakau di Indonesia. Dengan adanya antisipasi dari pemerintah atas gejolak yang ditimbul oleh fluktuasi inflasi dan kurs, dan juga produksi tembakau yang lebih berkualitas sehingga dapat meningkatkan dan memberikan dampak positif tehadap total ekspor.

\section{DAFTAR PUSTAKA}

Agung. A.W, (2010). Analisis pengaruh tingkat suku bunga SBI, harga minyak dunia, harga emas dunia, kurs rupiah, Indeks Nikkei 225, dan Indeks Dow Jones terhadap IHSG (studi kasus pada IHSG di BEI selama Periode 2000-2009). Dalam https://core.ac.uk/download/pdf/11722971.pdf. di akses Tanggal 18 Agustus 2019, Pukul 14.20 WIB.

Badan Pusat Statistik. (2018). Data ekspor tembakau Indonesia. Dalam https://www.bps.go.id/. Diakses tanggal 14 agustus 2019, pukul 12:12 
Badan Pusat Statistik. (2018). Data total ekspor perkebunan Indonesia. Dalam https://www.bps.go.id/. Diakses tanggal 14 desember 2019, pukul 12:00

Damodar N. Gujarati. (2007). Dasar-dasar ekonometrika. Erlangga: Jakarta.

Hamdy, Hady. (2001). Ekonomi Internasional Edisi ke-1. Ghalia Indonesia: Jakarta.

Maulida Azmi, dkk. (2016). Pengaruh harga tembakau internasional, jumlah produksi domestik dan nilai tukar terhadap nilai ekspor tembakau Indonesia Tahun 19852014. Jurnal Administrasi Bisnis (JAB). 38 (2)26.

Perdana, Taufik. (2010). Analisis faktor-faktor yang mempengaruhi ekspor The PTPN. Institut Pertanian Bogor: Bogor.

Putu dan Martini. (2015). Pengaruh luas lahan, jumlah produksi dan kurs dollar pada ekspor cengkeh di Indonesia. Jurnal Ekonomi Pembanguan Universitas Udayana. $4(1) 26-27$

Soekartiwi. (2005). Prinsip Dasar ekonomi pertanian: teori dan aplikasi. Raja Grafindo Persada: Jakarta.

Basuki, Sulistyo. (2010). Metode penelitian. Penaku: Jakarta

Tambunan, Tulus. (2001). Perekonomian Indonesia. Ghalia: Jakarta.

Wahyu, W. (2011). Analisis ekonometrika dan statistika dengan eviews, Edisi Ke-3. Unit Penerbit dan Percetakan (UPP STIM YKPN) : Yogyakarta.

Hasibuan,LS; R Nurjanah, E Umiyati. (2019).Faktor-faktor yang mempengaruhi inflasi Provinsi-Provinsi di Sumatera, e-Jurnal Perspektif Ekonomi dan Pembangunan Daerah 8 (1), 1-14

Zamzami,Z; \& D Hastuti, S Sunargo. (2020). Pengaruh ekspor asia timur terhadap pengangguran di Indonesia, Jurnal Paradigma Ekonomika, 15 (1), 59-74 